\title{
Improving Student Achievement Using Flipchart Based Cooperative Learning in Tulungagung
}

\author{
Abd. Aziz ${ }^{1, *}$, Nadia Roosmalita Sari ${ }^{2}$, Annas Ribab Sibilana ${ }^{1}$, Muniri ${ }^{1}$, Surahmat $^{3}$ \\ ${ }^{1}$ Faculty of Education and Teacher Training, IAIN Tulungagung, Tulungagung, Indonesia \\ ${ }^{2}$ Faculty of Economics and Business in Islam, IAIN Tulungagung, Tulungagung, Indonesia \\ ${ }^{3}$ Faculty of Teacher Training and Education, Universitas Islam Malang, Indonesia
}

Received June 22, 2020; Revised July 27, 2020; Accepted August 25, 2020

\section{Cite This Paper in the following Citation Styles}

(a): [1] Abd. Aziz, Nadia Roosmalita Sari, Annas Ribab Sibilana, Muniri, Surahmat, "Improving Student Achievement Using Flipchart Based Cooperative Learning in Tulungagung," Universal Journal of Educational Research, Vol. 8, No. 10, pp. 4628-4633, 2020. DOI: 10.13189/ujer.2020.081031.

(b): Abd. Aziz, Nadia Roosmalita Sari, Annas Ribab Sibilana, Muniri, Surahmat (2020). Improving Student Achievement Using Flipchart Based Cooperative Learning in Tulungagung. Universal Journal of Educational Research, 8(10), 4628-4633. DOI: 10.13189/ujer.2020.081031.

Copyright $\bigcirc 2020$ by authors, all rights reserved. Authors agree that this article remains permanently open access under the terms of the Creative Commons Attribution License 4.0 International License

\begin{abstract}
This study aims at improving student learning achievement using flip chart medium design based on cooperative learning method. To prove this goal, this study is focused on (1) knowing the effectiveness of learning media (flip chart) applied to thematic subjects for grade 2 elementary schools in Rejotangan District on student learning outcomes; (2) finding out whether there is an influence of the use of flip chart learning medium on the thematic subjects learning outcomes of grade 2 elementary school students in Rejotangan Districts. The population of this study was 12 elementary school institutions in Rejotangan, Tulungagung subdistrict, by setting 4 schools as samples which were divided into 2 schools as experimental classes (flip chart learning design) and 2 schools as control classes (conventional learning). The sample selection is done using a simple random sampling technique and the data analysis techniques carried out descriptively and inferentially. The results of this study indicate that flip chart learning medium based on cooperative learning method can be said to be quite effective in improving student learning outcomes. This is evidenced by using the N-Gain Score test with a significance level of $62 \%$, while conventional media is not effectively applied to thematic subjects with a percentage of $8 \%$. Furthermore, Mann Whitney test results show that the significance score is 0.00 . Therefore, it can be seen that there is a positive influence on the use of flip chart learning medium on learning outcomes in thematic subject of grade 2 elementary school in Tulungagung subdistrict. The
\end{abstract}

results recommend that using cooperative learning with flip chart as a medium is very effective in improving student learning outcomes on thematic subjects of elementary schools lower graders.

Keywords Students' Achievement, Flipchart, Cooperative Learning

\section{Introduction}

Waste often becomes an environmental problem that is still hotly discussed. The existence of waste cannot be separated from the human life cycle. As the human population increases, so does the amount of waste produced. For example, according to Environmental Services records, the waste volume entering the Segawe Final Disposal Site in Tulungagung during 2017 has reached 80 to 100 tons per day. This is due to people unknowledgeable of waste type and its use, so that waste that should be chosen and reuse is useless.

Waste that is not treated properly has an impact on the community environment. First, household waste can affect the quality of clean water and it requires a long time to restore this situation. Second, it can cause air pollution, as a result of waste decomposition by microorganisms. Third, it can trigger the emergence of diseases that can harm the human health [1]. Therefore, efforts are needed to tackle 
the existence of waste in the Indonesian community. Organic waste is now widely used as material for composting, or biogas, but inorganic waste is very minimal in management [2]. Theoretically, inorganic waste can be processed in three ways. Those are reuse, reduce, and recycle. Reuse is to directly reuse the waste with the same or different functions. Reduce is to reduce the use of goods to minimize waste generation. Meanwhile recycle is to reuse processed waste.

Considering the problems and impacts of waste, an idea to recycle waste into more useful stuff and can be used for the learning process has emerged. The recycle is to recycle the used calendar into an interesting learning media that is flipchart. Interesting learning media can used independently to achieve competence [3], such as Flipchart. Flipchart is a chart or feedback chart that presents information. The parts of the message are written or outlined in separate sheets, and then the sheets are bundled into one. To use the flipchart is only to turn the sheets one by one according to the message delivered [4]. Creating a new flipchart requires a lot of time and money, so that not many teachers want to use flipchart for learning.

Based on the observations, when the thematic learning process took place in several MI (Islamic Elementary School) Rejotangan areas, students were less enthusiastic in learning. The teacher presents learning in conventional methods, so students tend to be passive. The teacher is still the single actor in the class while the criteria for thematic learning use students-centered approach rather than the teacher-centered. So, in thematic learning, it is necessary to use interesting learning media such as flipcharts to make students more enthusiastic, active, and finally, the learning outcomes can be achieved optimally. In other side, the mathematic needs media content as a stimulation [5]. Researchers propose this method based on observations and literature studies that researchers read, namely research conducted by [6].

Flip chart is a two-dimensional learning medium that can help students understand abstract concepts to be more contextual. Based on the cognitive development theory put forward by Piaget in [7], children in primary school age enter a concrete operational stage. It means that the majority of students in elementary schools have been able to understand symbols, concepts and theories but need concrete objects as an intermediary to understand.

The results of research conducted by Pratama on the use of flipchart medium showed that teachers became easier to convey material to students. Therefore, students were more motivated and easier to understand the material [8]. This is in line with the research conducted by Desi Eka P. that the use of flipchart medium on thematic learning models with animal and plant themes can improve student learning outcomes [4]. Based on these results, it was found that Flipchart medium is effective to be used in the learning process.

Based on the explanation, it needs an effort to make the learning process more interesting, active, effective and fun. If students feel happy during learning, then there is no need to force them to learn. Students are no longer just being told but looking to understand a concept or theory. Cooperatively, students can work together with classmates so that they can build social competence among each student. The purposes of this study are; first is to find out the effectiveness of the learning medium (flipchart) which is implemented in thematic subjects for grade 2 elementary school students in Rejotangan against student learning outcomes and second is to find out whether there is an influence of the use of flipchart learning medium on the learning outcomes of grade 2 elementary schools students in Rejotangan District on thematic subjects.

\section{Related Works}

A flip chart is one of the learning medium developed by utilizing the used calendar to be more efficient. The main purpose of this research is to improve students' learning outcomes. Flipchart design is a form of visual medium that is chosen and is part of the learning strategy. The selection of medium is adjusted to the secondary level students of elementary school, where [9] students at this level need visualization of ideas or concepts that are difficult to understand if it is spoken, for example in the form of pictures, charts, diagrams, etc.

This flip chart is considered to be quite good and helps teachers and students in the learning process. Likewise, for teachers, it will be more efficient in terms of time and use of the blackboard so the teacher can continue the lesson without chasing material under the time limitation. Flip chart medium is simple, economical, easily obtained materials, can convey summaries, able to overcome the space and time limitation without requiring special equipment and easy placement. Some strategies that have been successfully implemented in the learning process are e-learning [10], web based learning [11], Moodle [12], animation [13], audiovisual [14], and games [15].

Edward et al. (2019) using Moodle as a medium to improve student competencies especially oriental music at Senior Secondary Level in Sri Lanka [12]. This study analyzes the research in applying Blended Learning (BL) as an approach. The blended Learning strategy shows that there is a significant increase in musical academic competence as evidenced by the experimental group's post-test score of 71.75 , in which this value is higher than the control group with a score of 52.07.

Kaushal \& Panda (2019) use animation as a medium to produce better learning. The animations used in this research are 2D, 3D, and diagram animation. The study statistically proved that prior knowledge was an important factor while using animation-based teaching styles, therefore it was implemented in HPK students. Meanwhile, the spatial ability is not an important factor because the 
level of students' spatial ability is positively influenced by animation learning strategies. This fact can help educators to design learning methodologies to improve learning outcomes [13].

Sapto Haryoko (2019) uses audiovisual medium as a learning strategy in computer network engineering courses [14]. The results showed that the average posttest score of the experimental group students was higher than the control group with a value of 86.00 . It can be concluded that audiovisual as a learning medium is far more effectively implemented in computer network engineering courses compared to conventional approaches.

Bin Shyan Jong et al. (2013) uses games as a strategy in classroom learning. Game-based learning takes many forms, including virtual reality, role-playing, and doing assignments [15]. The research investigates the implementation of game-based cooperative learning in the operating system. The results of the study indicate that students are highly motivated to learn with these game-based learning strategies.

This study tried to implement a flipchart as a learning medium to improve student learning outcomes with cooperative learning strategies. Based on the research of [16], learning media can be implemented using cooperative learning strategies.

\section{Method (Flipchart Learning Design)}

The variables of this study were student learning outcomes for thematic subject grade 2 elementary school using flipchart medium. Student learning outcomes are measured using Pretest and Posttest. Furthermore, to provide a clear picture related to the variables studied through the application of two learning techniques. They are student learning outcomes by implementing the proposed medium (flipchart) and learning outcomes by applying conventional techniques.

The population in this study was $12^{\text {th }}$-grade elementary school students in Rejotangan Tulungagung District. This study took samples for testing as many as 4 schools which were divided into control classes and experimental classes. There are 2 schools for control classes (conventional technique) and 2 schools for the experimental classes (flipchart learning). The selection of this sample is done randomly by using a simple random sampling technique [14].

Next, the implementation phase of the experiment begins with the implementation of flipchart medium in thematic subjects. The implementation was divided into several stages; (a) the preparation stage by observing in elementary schools in Rejotangan District and (b) the learning implementation stage by using flipchart medium which is applied to cooperative learning technique models in the experimental class and providing learning using conventional techniques in the control class.

The instrument was developed based on the thematic subject syllabus and elaborated from the subject to sub-subjects and indicators to be achieved. Developing the tests using the results of learning outcomes model with multiple-choice questions [17]. To guarantee the quality and weight of the questions, the test items were developed with a question analysis model but can reflect students' comprehensive abilities. The pretest was given before the learning process while the posttest was given after the learning is carried out. Students' improvement in learning outcomes was measured by looking at the positive value between the average final score and initial score difference.

This research uses descriptive and inferential analysis techniques. Descriptive analysis was used to describe student scores in the experimental and control groups. Meanwhile, inferential analysis was used to test the hypothesis that there are differences in student learning outcomes between the experimental group taught using flip-chart medium and control group taught using conventional

The effectiveness of flipchart learning design is done by analyzing the test result data which is measured by using the normalized gain score calculation [18] [19]. The following equation is used to calculate the Gain Score.

Normalized Gain $(<g>)=\frac{\text { Posttest score-Pretest score }}{\text { Ideal score-Pretest score }}$

The results of the Gain Score calculation are drawn up based on Table 1 .

Table 1. N-Gain Effectiveness Interpretation Category

\begin{tabular}{|c|c|}
\hline Percentage & Description \\
\hline$<40$ & Ineffective \\
\hline $40-55$ & Less Effective \\
\hline $56-75$ & Quite Effective \\
\hline$>76$ & Effective \\
\hline
\end{tabular}

\section{Findings}

\subsection{Normalized Gain Score Testing (N-Gain Score)}

The sample in this study was four elementary schools with 30 students of each. Data of the pretest and posttest results that have been tested in the experimental class and the control class are shown in Table 2. 
Table 2. Data of Pretest and Posttest Result

\begin{tabular}{|c|c|c|c|c|}
\hline \multirow{2}{*}{ No } & \multicolumn{2}{|c|}{ Control } & \multicolumn{2}{c|}{ Experiment } \\
\cline { 2 - 5 } & Pretest & Posttest & Pretest & Posttest \\
\hline 1 & 72 & 84 & 70 & 86 \\
\hline 2 & 78 & 78 & 73 & 85 \\
\hline 3 & 79 & 84 & 81 & 80 \\
\hline 4 & 88 & 88 & 72 & 93 \\
\hline 5 & 87 & 87 & 71 & 87 \\
\hline 6 & 72 & 77 & 78 & 90 \\
\hline 7 & 71 & 77 & 75 & 90 \\
\hline 8 & 78 & 84 & 84 & 84 \\
\hline 9 & 75 & 77 & 79 & 91 \\
\hline 10 & 84 & 84 & 80 & 76 \\
\hline$\ldots$ & $\ldots$ & $\ldots$ & $\ldots$ & $\ldots$ \\
\hline 60 & 68 & 72 & 70 & 95 \\
\hline
\end{tabular}

After obtaining the results of the pretest and posttest as shown in Table 2, the Normalized Gain Score calculation is done using Equation 1. The Normalized Gain Score calculation results show that the average N-Gain score for the experimental class (Flipchart) is 62.18 or $62 \%$. If conclusions are drawn based on Table 1, the number is classified as quite effective with a minimum value of $38 \%$ and a maximum value of $85 \%$. The results of the N-Gain score calculation shown in Table 3 .

Table 3. Result of N-Gain Score Test

\begin{tabular}{|c|c|c|}
\hline Class & Control & Experiment \\
\hline Mean & 7,6739 & 62,1807 \\
\hline Std. Error & 0,5625 & 1,2160 \\
\hline Minimum & 0,00 & 37,50 \\
\hline Maximum & 20,00 & 85,00 \\
\hline
\end{tabular}

Meanwhile, the N-Gain score for the control class (conventional technique) is 7.67 or $8 \%$. If conclusions are drawn based on Table 1, then the score is classified as ineffective, with a minimum value of $0 \%$ and a maximum value of $20 \%$.

Based on the results of the N-Gain Score in each class (experiment and control), it can be concluded that the use of flipchart learning medium is effective enough to be used to improve learning outcomes in thematic Subjects of grade 2 elementary school students. Meanwhile, the use of conventional methods in the control class is not effective in improving learning outcomes in Thematic Subjects of grade 2 elementary school.

\subsection{Hypothesis Testing}

Furthermore, a t-test is performed to prove the hypothesis that has been formulated in the first section. The hypothesis that will be proven is the increase in Thematic subject learning outcome of students in grade 2 elementary schools using flipcharts is significantly higher than students who get material using conventional methods.

Statistical test analysis for pretest and posttest data is processed through several tests. They are the normality test, homogeneity test, and t-test. If it is proven that the data is not normally distributed, the Mann-Whitney test will be conducted.

\subsection{Data Normality Test}

A normality test is one of the requirements that must be met before parametric statistical analysis is performed. This test aims to determine whether or not the research data is normally distributed. In parametric statistics, there are two types of normality tests used, the Kolmogorov-Smirnov test and the Shapiro-Wilk test [20]. The data that will be tested for normality are the pretest and posttest data shown in Table 2. After the data normality test is performed, the data is presented in Table 4.

Based on the results of the normality test shown in Table 4 , it can be seen that the significant value generated through the Kolmogorov-Smirnov and Shapiro-Wilk tests is 0.00 . Referring to the decision of data normality test, $0.00<0.05$ indicates that the data is not normally distributed. These results indicate that the data are included in non-parametric statistics. Therefore, further testing using the Mann Whitney test is done. Mann Whitney aims to determine whether there are differences in the average of two unpaired samples.

Table 4. Result of Data Normality Test

\begin{tabular}{|c|c|c|c|c|c|c|c|}
\hline \multirow{2}{*}{ Class } & \multicolumn{3}{|c|}{ Kolmogorov-Smirnov $^{\mathbf{a}}$} & \multicolumn{3}{c|}{ Shapiro-Wilk } \\
\cline { 3 - 9 } & & Statistic & df & Sig. & Statistic & Df & Sig. \\
\hline \multirow{5}{*}{ Learning Outcomes } & Pretest (Control) & .220 & 60 & .000 & .827 & 60 & .000 \\
\cline { 2 - 9 } & Posttest (Control) & .189 & 60 & .000 & .839 & 60 & .000 \\
\cline { 2 - 9 } & Pretest (Experiment) & .230 & 60 & .000 & .826 & 60 & .000 \\
\cline { 2 - 9 } & $\begin{array}{c}\text { Posttest } \\
\text { (Experiment) }\end{array}$ & .309 & 60 & .000 & .831 & 60 & .000 \\
\hline
\end{tabular}


Table 5. Result of Mann Whitney Test

\begin{tabular}{|c|c|}
\hline \multicolumn{2}{|c|}{ Learning Outcomes } \\
\hline Mann-Whitney U & 29.000 \\
\hline Wilcoxon W & 1859.000 \\
\hline Z & -9.409 \\
\hline Asymp. Sig. (2-tailed) & .000 \\
\hline
\end{tabular}

Based on the Mann Whitney test results shown in Table 5 , it is known that the Asymp value. Sig. (2-tailed) of 0.00. Referring to the basis of decision making, the value of 0.00 $<0.05$ indicates that the hypothesis is accepted that there are differences in Thematic learning outcomes of students in grade 2 elementary school, so it can be concluded that there is an influence on the cooperative learning based using flipchart learning medium on learning outcomes in Thematic subjects of grade 2 elementary school in Rejotangan District.

\section{Conclusions}

Based on the results of the study, it is known that the proposed learning medium (flipchart) can be said to be quite effective in improving student learning outcomes. This can be proven by using the N-Gain Score test with a significance level of $62 \%$, while conventional media is not effective to be applied to thematic subjects with a percentage of $8 \%$.

Furthermore, the Mann Whitney test shows that the significant value is 0.00 . The value indicates that there is an influence on learning outcomes using flipchart medium based on cooperative learning in thematic subject for Grade 2 elementary school in Rejotangan District.

\section{REFERENCES}

[1] Rosmidah Hasibuan, “Analisis Dampak Limbah/Sampah Rumah Tangga Terhadap Pencemaran Lingkungan Hidup (Analysis of Impact of Household Waste / Waste on Environmental Pollution)," Jurnal Ilmiah “Advokasi," vol. 4, no. 1, hlm. 42-52, 2016.

[2] H. P. Putra dan Y. Yuriandala, "Studi Pemanfaatan Sampah Plastik Menjadi Produk dan Jasa Kreatif (Study of Utilizing Plastic Waste into Creative Products and Services)," jstl, vol. 2, no. 1, hlm. 21-31, Mar 2010, doi: 10.20885/jstl.vol2.iss1.art3.

[3] R. A. Liliana, W. Raharjo, I. Jauhari, dan D. Sulisworo, "Effects of the Online Interactive Learning Media on Student's Achievement and Interest in Physics," Universal Journal of Educational Research, vol. 8, no. 3B, hlm. 59-68, Mar 2020, doi: 10.13189/ujer.2020.081507.

[4] D. E. Pratiwi, "Penerapan Media Papan Balik (Flipchart) Pada Pembelajaran Tematik Untuk Meningkatkan Hasil
Belajar Siswa Sekolah Dasar (Application of Flipchart Media on Thematic Learning to Improve Learning Outcomes of Primary School Students)," vol. 01, hlm. 10, 2013.

[5] F. C. Lunenburg, "Critical Thinking and Constructivism Techniques for Improving Student Achievement,” hlm. 9.

[6] Tatiana Borodina, Alfiya Sibgatullina, dan Anna Gizatullina, "Developing Creative Thinking in Future Teachers as a Topical Issue of Higher Education," Journal of Social Studies Education Research, vol. 4, no. 10, 2019.

[7] Zana Babakr, Pakstan Mohamedamin, dan Karwan Kakamad, "Piaget's Cognitive Developmental Theory: Critical Review," Education Quarterly Reviews, vol. 2, no. 3, 2019.

[8] R. P. Putra, "Pengembangan Media Pembelajaran Flip Chart Berbahan Dasar Bambu (Development of Flip Chart Learning Media Made from Bamboo)," vol. 7, hlm. 16, 2019.

[9] Salim dan Andi Muh. Fahresyah, "Efektivitas Media Kartu Variabel dan Media Flip Chart Terhadap Hasil Belajar Matematika Siswa Kelas VIII SMP Negeri 4 Kendari (Media Effectiveness of Variable Card and Flip Chart Media on Mathematics Learning Outcomes of Class VIII Students of SMP Negeri 4 Kendari)," Indonesian Digital Journal of Mathematics and Education, vol. 4, no. 7, hlm. 462-472, 2017.

[10] L. Shen, M. Wang, dan R. Shen, "Affective e-Learning: Using 'Emotional' Data to Improve Learning in Pervasive Learning Environment," hlm. 15, 2020.

[11] S.-W. Chou dan C.-H. Liu, "Learning effectiveness in a Web-based virtual learning environment: a learner control perspective: Web-based virtual learning environment," Journal of Computer Assisted Learning, vol. 21, no. 1, hlm. 65-76, Feb 2005, doi: 10.1111/j.1365-2729.2005.00114.x.

[12] C. N. Edward, D. Asirvatham, dan G. Johar, "The Impact of Teaching Oriental Music Using Blended Learning Approach," Malaysian Journal of Learning and Instruction, vol. 16, no. 1, hlm. 81-103, 2019.

[13] R. K. Kaushal dan S. N. Panda, "A Meta Analysis on Effective Conditions to Offer Animation Based Teaching Style," Malaysian Journal of Learning and Instruction, vol. 16, no. 1, hlm. 129-153, 2019.

[14] Sapto Haryoko, "Efektivitas Pemanfaatan Media Audio-Visual sebagai Alternatif Optimalisasi Model Pembelajaran (The Effectiveness of Utilizing Audio-Visual Media as an Alternative Optimization of Learning Models)," JurnalEdukasi@Elektro, vol. 5, no. 1, hlm.1-10, 2009.

[15] Bin-Shyan Jong, Chien-Hung Lai, Yen-Teh Hsia, Tsong-Wuu Lin, dan Cheng-Yu Lu, "Using Game-Based Cooperative Learning to Improve Learning Motivation: A Study of Online Game Use in an Operating Systems Course," IEEE Trans. Educ., vol. 56, no. 2, hlm. 183-190, Mei 2013, doi: 10.1109/TE.2012.2207959.

[16] T. Hainey, T. M. Connolly, M. Stansfield, dan E. A. Boyle, "Evaluation of a game to teach requirements collection and analysis in software engineering at tertiary education level," Computers \& Education, vol. 56, no. 1, hlm. 21-35, Jan 2011, doi: 10.1016/j.compedu.2010.09.008. 
[17] N. Ramadoan, D. Sulisworo, I. Jauhari, dan W. Raharjo, "Assembling the Computer Simulation on Hypothetical Deductive Thinking Approach Learning to Improve Learning Achievement," Universal Journal of Educational Research, vol. 8, no. 3B, hlm. 41-50, Mar 2020, doi: 10.13189/ujer.2020.081505.

[18] K. L. Nani dan Y. S. Kusumah, "The Effectiveness Ofict-Assisted Project- Based Learning In Enhancing Students' Statistical Communication Ability," International
Journal of Education and Research, vol. 3, no. 8, hlm. 187196, 2015.

[19] G. J. Mellenbergh, "A Note on Simple Gain Score Precision," hlm. 3 .

[20] H. Alizadeh Noughabi, "Two Powerful Tests for Normality," Ann. Data. Sci., vol. 3, no. 2, hlm. 225-234, Jun 2016, doi: $10.1007 / \mathrm{s} 40745-016-0083-\mathrm{y}$. 